DOI: https://doi.org/10.24867/15IH03Jurosevic

\title{
РАЗВОЈ КОРИСНИЧКЕ АПЛИКАЦИЈЕ ЗА ГЕНЕРИСАЊЕ НАЛОГА ЗА УТОВАР СА ПОДРШКОМ ПРОШИРЕНЕ РЕАЛНОСТИ
}

\section{DEVELOPMENT OF THE USER APPLICATION FOR CREATING SHIPPING ACCOUNT WITH SUPPORT OF THE AUGMENTED REALITY}

\author{
Владимир Јурошевић, Факултет техничких наука, Нови Сад
}

\section{Област - МЕХАТРОНИКА}

Кратак садржај - Рад је посвећен развоју корисничке апликачије за генерисање налога за утовар са подршком проширене реалности. Бави се оптимизацијом прочеса слагања транспортне амбалаже (транспортних кутија) на транспортно помоћно средство (равну палету), коришћењем претходно развијеног алгоритма [2] имплементираног у апликачију проширене реалности [1]. Тако се ужи процес унутар складишта повезује са иирим процесима унутар производног система на аутоматизован начин. У раду су дати детаљни поступци инсталације и коришћења апликачије. Пропратно су дате потешкоће, недостации и ограничења која су се јављала у оквиру практичне имплементације рада.

Кључне ријечи: Корисничка апликација, проширена реалност, паметне наочаре, слагање амбалаже, равна палета

Abstract - The paper is dedicated to the development of a user application for generating loading orders with augmented reality support. It deals with the optimization of the process of stacking transport packaging (transport boxes) on a transport aid (flat pallet), using a previously developed algorithm [2] implemented in an augmented reality application [1]. Thus, the narrower process within the warehouse is connected to the wider processes within the production system in an automated way. The paper presents detailed procedures for installing and using the application. Accompanying difficulties, shortcomings and limitations that occurred within the practical implementation of the work are given.

Keywords: User application, augmented reality, smart glasses, stacking packaging, flat palette

\section{1. УВОД}

Потешкоће и проблеми који се јављају приликом обављања практичних задатака у производним процесима при руковању предметима рада, завршном паковању готових производа и формирању збирних паковања доводе до интензивирања научних истраживања и инжењерских приступа ка проналажењу конкретних рјешења. Један од проблема

\section{НАПОМЕНА:}

Овај рад је проистакао из мастер рада чији ментор је био др Слободан Дудић, ванр. проф. који се јавља јесте и поступак правилног формирања збирног паковања слагањем транспортне амбалаже (транспортних кутија) на транспортно помоћно средство (равну палету), односно проблем паковања палете (енгл. Pallet Loading Problem). У том својству је настао један овакав рад који радницима у производним процесима омогућава олакшање поменутог поступка уз помоћ проширене реалности (енгл. Augmented Reality). Проширена реалност омогућује убацивање виртуелних објеката у стварни тродимензиони простор човјека. Поменуте објекте корисник опажа као да су стварни. Коришћењем савремених технологија жели се повећати општа ефикасност производног система, која укључује и процесе у складишту.

\section{2. ПРИМЈЕНА ПРОШИРЕНЕ РЕАЛНОСТИ УЗ ПОМОЋ ПАМЕТНИХ НАОЧАРА}

Примјена технологије проширене реалности је остварена уз помоћ паметних наочара. Кориснички интерфејс наочара је веома сличан интерфејсу на паметним телефонима, тако да је адаптација корисника поједностављена.

\section{1. Паметне наочаре „Vuzix Blade“}

У табели 1 изложене су важније техничке спецификације за овај рад сходно подацима од произвођача, компаније „Vuzix“ [3] и страници [4].

Табела 1. Техничке спецификације паметних наочара

\begin{tabular}{|l|l|}
\hline $\begin{array}{l}\text { Оптика и } \\
\text { електроника }\end{array}$ & $\begin{array}{l}\text { Прозирна сочива } \\
\text { Екран у боји на десном сочиву } \\
\text { Процесор - Quad Core ARM CPU } \\
\text { Камера - 8 MP са аутофокусом }\end{array}$ \\
\hline Меморија & $\begin{array}{l}\text { 1 GB системске RAM и 8 GB } \\
\text { интерне меморије за податке }\end{array}$ \\
\hline $\begin{array}{l}\text { Управљачке } \\
\text { акције }\end{array}$ & $\begin{array}{l}\text { Преко дршке осјетљиве на додир } \\
\text { Са других уређаја }\end{array}$ \\
\hline Батерија & $\begin{array}{l}\text { Пуњива LiРо батерија од 470 mAh } \\
\text { Могући додатак екстерне батерије }\end{array}$ \\
\hline Конекције & $\begin{array}{l}\text { Бежично 2.4 GHz WiFi и Вluеtooth } \\
\text { Місго USB }\end{array}$ \\
\hline Софтвер & Инсталација сопствених апликација \\
\hline Маса & 90 g \\
\hline Видно поље & $19-28$ степени \\
\hline
\end{tabular}


Слика 1 даје изглед паметних наочара „Vuzix Blade“ коришћених у оквиру овог рада.

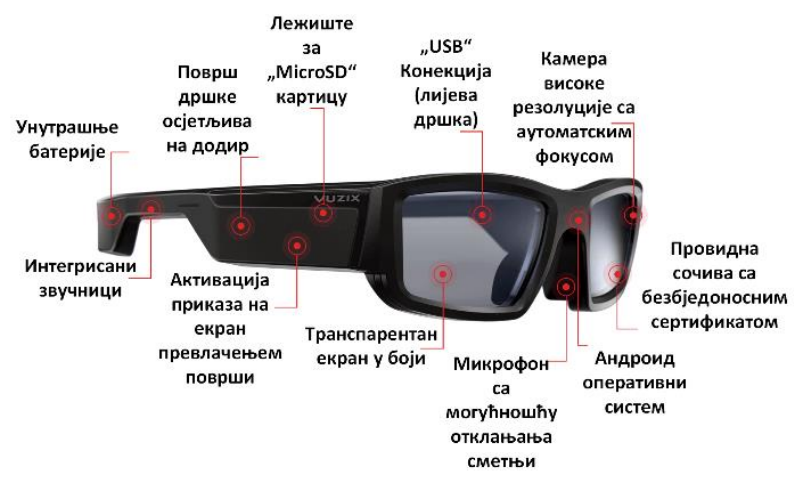

Слика 1. Изглед паметних наочара „, Vuzix Blade“ [3]

\section{2. Инсталација апликације на „Vuzix Blade“}

Поступак припреме инсталације апликације на паметне наочаре се може извршити ако се испоштују наредни кораци:

1) омогућити USB пренос података - USB debugging Settings -> Device -> USB Mode -> MTP;

2) активирати режим рада за развој апликација Developer mode.

Упутство дато на сајту произвођача [5] ;

3) активирати USB debugging -

Settings->System->Dev Options -> USB Debugging->On;

4) инсталирати ADB (енгл. Android Debug Bridge) на рачунар;

5) повезати паметне наочаре са рачунаром преко Micro USB кабла;

6) инсталирати (пребацити) апликацију на паметне наочаре путем ADB-a.

Апликација за палетирање има екстензују *.apk. Након што се испуни припрема инсталације, потребно је још у оквиру шестог корака унијети завршну команду унутар командне линије рачунара:

$$
\text { adb install <ime_aplikacije>.apk }
$$

гдје <ime_aplikacije> означава назив извршног фајла, тј. назив апликације која се пребацује са рачунара на паметне наочаре. Унос завршне команде и потврда инсталације су приказани на слици 2.

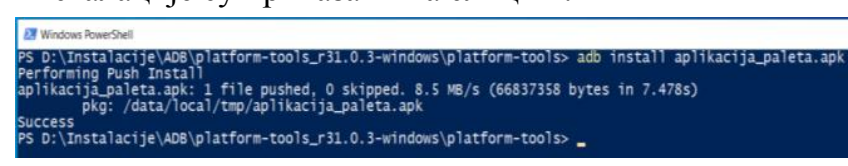

Слика 2. Команда за инсталащију апликаџије

Покретање апликације проширене реалности на паметним наочарама је приказано на слици 3. На лијевој страни слике је приказана могућност брзог покретања апликације из почетног менија. На десној страни слике је приказана могућност проналажења и покретања апликације на основу путање:

$$
\text { Settings->Apps->Slaganje na paletu }
$$

\footnotetext{
${ }^{1}$ Како би се заиста приступило овој страници, неопходно је бити улогован на сајт произвођача Vuzix.
}

\section{3. КОРИСНИЧКА АПЛИКАЦИЈА ЗА ГЕНЕРИСАЊЕ НАЛОГА ЗА УТОВАР}

Савремена складишта нису само лагери производа и центри за распоређивање пријема и слања производа са лагера. Складишта постају предузећа унутар предузећа [6]. Због тога је потребно повезати сектор менаџмента са магацином у оквиру складишта. У савременом свијету већина складишта се и даље ослања на папиролошки прилаз у поступку обављања операција [7]. Резултат корисничке апликације јесте генерисан налог за утовар у *.pdf формату погодном за чување и штампање у папирној форми. Слика 3 приказује унијете одговарајуће податке, чиме је апликација спремна за генерисање налога за утовар.

Генерисани QR код ће се скенирати путем паметних наочара како би се преузели подаци са налога у апликацију проширене реалности.

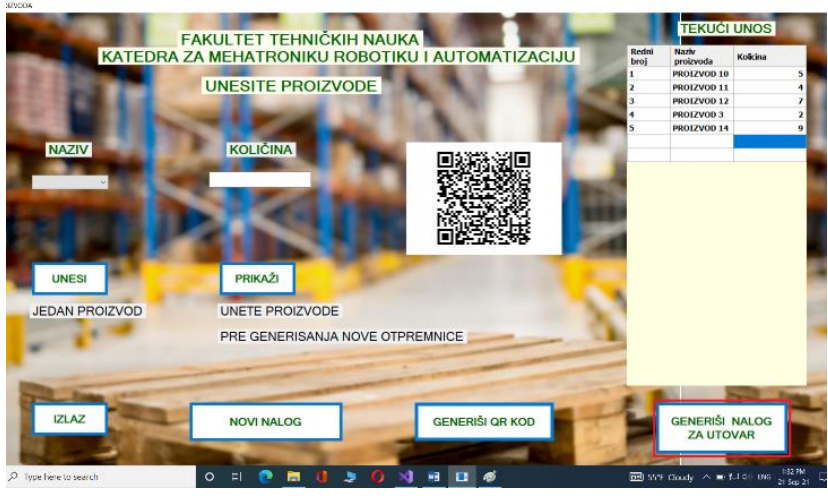

Слика 3. Изглед корисничке апликащчје

\section{4. ИМПЛЕМЕНТАЦИЈА АПЛИКАЦИЈЕ НА ПАМЕТНИМ НАОЧАРАМА}

Када је транспортна амбалажа у виду транспортних кутија припремљена за слагање на палету, потребно је изршити скенирање QR кода са налога за утовар како би апликација проширене реалности добила све неопходне информације о амбалажи која је на располагању за слагање.

\section{1. Примјена апликације проширене реалности}

Апликација проширене реалности је развијена у оквиру рада [1], а алгоритам за слагање кутија у оквиру ње у раду [2]. За успјешну имплементацију поменуте апликације у реалним условима рада, потребно је да радник прође кроз неколико корака.

Најприје треба да укључи наочаре и стави их, тако да гледа кроз сочива. Садржај апликације се приказује на екрану, који се налази на десном сочиву. Рад апликације се започиње њеним покретањем, на један од два начина праказана на слици 4.
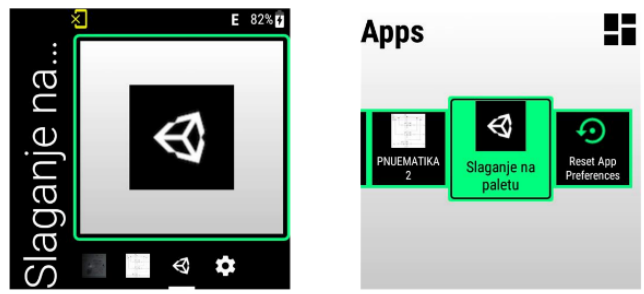

Слика 4. Покретање апликације на наочарама 
Кориснички интерфејс апликације приказан је на слици 5. Редослијед операција које радник треба да предузме означени су словним ознакама од а до г.

Након што скенира QR код са налога за утовар, радник кликом треба да потврди генерисање алгоритма. Новим кликом омогућава приказ прве виртуелне кутије. У случају успјешног приказа прве кутије, закључује се да је камера наочара препознала маркер палете.

У супротном треба кориговати угао између наочара и палете док се заиста не прикаже виртуелна кутија.

Неопходни подаци за генерисање алгоритма скенирани са QR кода дати су у табели 2.

\section{5. РЕЗУЛТАТИ}

Изглед генерисаног налога за утовар је приказан на слици 6. Треба напоменути да налог није настао уређивањем у неком од програма за обраду текста и слика већ као резултат корисничке апликације креиране у оквиру овог рада.

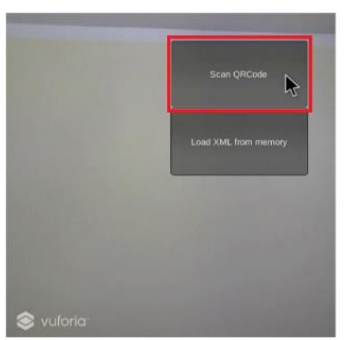

a)

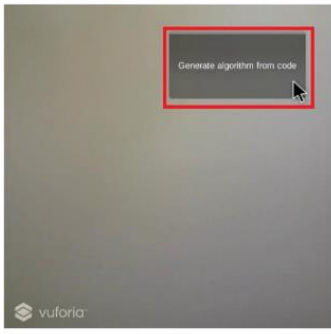

б)

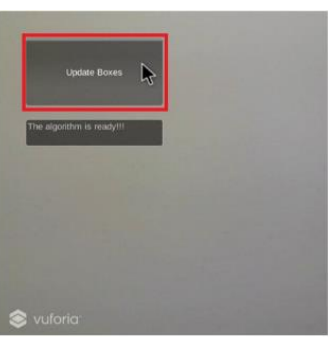

в)

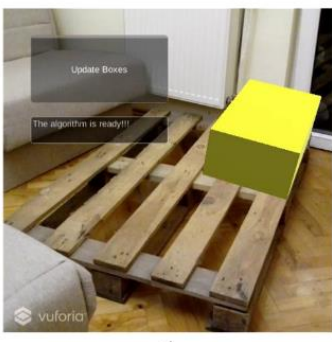

Слика 5. Редослијед операција унутар апликације

Табела 2. Примјер коришћених података за тестну верзију слагања

\begin{tabular}{|c|c|c|c|c|}
\hline \multicolumn{3}{|c|}{ Димензије [mm] } & \multirow{2}{*}{ Количина } & \multirow{2}{*}{ Боја } \\
\hline Ширина & Дужина & Висина & 5 & BROWN \\
\hline 480 & 410 & 200 & 4 & MAGENTA \\
\hline 490 & 420 & 200 & 7 & TAN \\
\hline 410 & 430 & 200 & 2 & YELLOW \\
\hline 600 & 330 & 200 & 9 & MAROON \\
\hline
\end{tabular}

FAKULTET TEHNIČKIH NAUKA KATEDRA ZA MEHATRONIKU, ROBOTIKUI AUTOMATIZACIJU

\section{NALOG ZA UTOVAR}

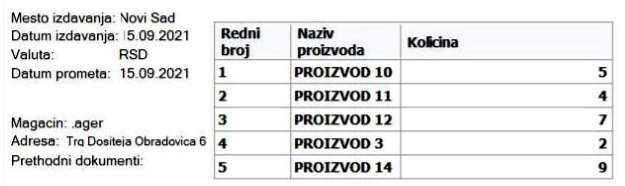

\begin{tabular}{ccc}
\hline Robu izdao & & Robu primio \\
\hline Obračunao & M.P. & Odgovorno lice \\
\hline
\end{tabular}

Слика 6. Изглед генерисаног налога за утовар

На слици 7 приказан је резултат апликације проширене реалности којом су сложене све кутије са налога за утовар на равну палету. Приказане кутије су виртуелне, а радник на основу њиховог распореда треба да физички сложи стварну амбалажу на палету.
Једној виртуелној кутији одговара једна стварна амбалажа идентичних димензија са производима.

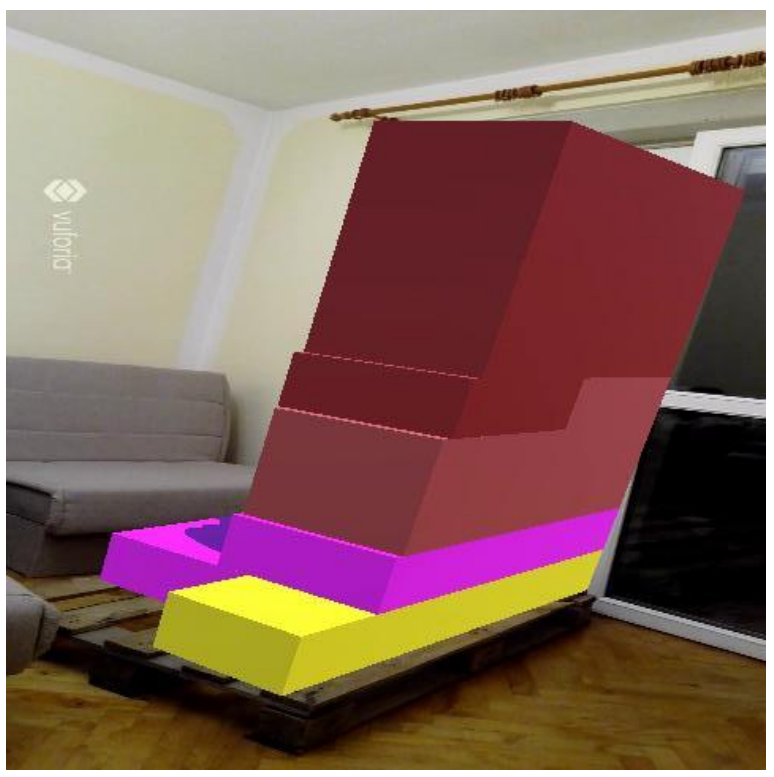

Слика 7. Сложене све виртуелне кутије

Када су све виртуелне кутије сложене, са екрана наочара нестаје дугме којим се врши додавање нове кутије. На тај начин радник схвата да је поступак слагања у потпуности завршен. 
Приликом рада са паметним наочарама до изражаја су дошли недостаци коришћеног модела наочара, који су довели до потешкоћа у практичном раду.

Наиме, несметано извршавање апликације било је Активно коришћење наочара са покренутом апликацијом проширене реалности је могуће свега око десетак минута. Након тога би се дршке наочара загријале. То је био јасан сигнал да се наочаре морају угасити и сачекати да се охладе.

Додатни недостатак јесте потреба за мобилним телефоном који има улогу показивача на екрану наочара, аналогно мишу код рачунара. Упркос поменутим недостацима, успјешно је показана функционалност тестиране апликације проширене реалности и алгоритма који се одвија у позадини, коришћењем паметних наочара.

Поред претходно наведеног, треба напоменути и то да је равна палета коришћена при тестирању већ раније експлоатисана и да је помало оштећена. Такође, при практичној имплементацији, палета је дјелимично била заклоњена другим инвентаром. Овакве околности додатно потврђују робусност апликације проширене реалности и алгоритма унутар ње.

\section{6. ЗАКЉУЧАК}

На основу резултата датих у одјељку 4 се види да је испуњен циљ рада. На основу уноса корисника у оквиру корисничке апликације је креиран налог за утовар са QR кодом. Скенирањем QR кода помоћу камере паметних наочара, потврђена је функционалност апликације проширене реалности и алгоритма унутар ње на паметним наочарама.

\section{7. ЛИТЕРАТУРА}

[1] Јекић, Б., Имплементација алгоритма за решавање проблема паковања палете у апликаџији проширене реалности, дипломски рад, Факултет техничких наука, Нови Сад, 2020.
[2] Тришић, Ж. Развој алгоритма за рјешавање проблема слагања транспортне амбалаже на транспортно помоћно средство, мастер рад, Факултет техничких наука, Нови Сад, 2020.

[3] Интернет страница : https://www.vuzix.com/products/blade-smart-glassesupgraded\#/blade-technical-specs, приступљено дана 22.08.2021.

[4] Интернет страница : https://vrexpert.com/news/vuzix-blade-upgraded-review/, приступљено дана 26.07.2021.

[5] Интернет страница :

https://www.vuzix.com/Developer/KnowledgeBase/Detail /1077, приступљено дана 25.08.2021.

[6] Дмитриев, А. В., Цифровизащия транспортнологистических услуг на основе применения технологии дополненной реальности, Вестник ЮжноУральского государственного университета. Серия: Экономика и менеджмент, vol. 12, no. 2, pp. 169178.,2008., URL:

https://cyberleninka.ru/article/n/tsifrovizatsiyatransportno-logisticheskih-uslug-na-osnove-primeneniyatehnologii-dopolnennoy-realnosti, [дата обращения 07.08.2021].

[7] DHL Trend Research [2014.] Augmented Reality in Logistics, Available: https://members.aixr.org/storage/csi_augmented_reality_r eport_290414.pdf, [Accessed on: 09/12/2021]

\section{Кратка биографија:}

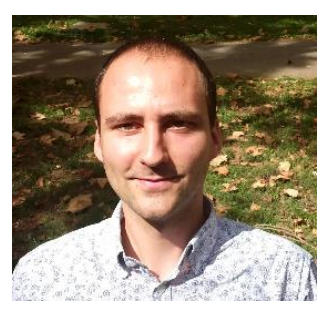

Владимир Јурошевић рођен у Доњецку (Украјина) 1997. год. Основне студије завршио 2020. на Факултету техничких наука. Мастер рад на Факултету техничких наука из области Мехатроника - Имплементација аутоматских система одбранио је 2021. год. 